Full length article

\title{
Growth, physiological and immune responses of Arapaima gigas (Arapaimidae) to Aeromonas hydrophila challenge and handling stress following feeding with immunostimulant supplemented diets
}

\author{
Marcia Kelly Reis Dias ${ }^{\mathrm{a}}$, Eliane Tie Oba Yoshioka ${ }^{\mathrm{b}}$, Anselmo Fortunato Ruiz Rodriguez ${ }^{\mathrm{c}}$, \\ Ricardo Amaral Ribeiro ${ }^{c}$, Fernando Sérgio Escócio Drummond Viana Faria ${ }^{c}$, \\ Rodrigo Otávio Almeida Ozório ${ }^{\mathrm{d}, \mathrm{e}}$, Marcos Tavares-Dias ${ }^{\mathrm{a}, \mathrm{b}, *}$ \\ ${ }^{\text {a }}$ Postgraduate Program in Tropical Biodiversity (PPGBio), Federal University of Amapá (UNIFAP), Macapá, AP, Brazil \\ ${ }^{\mathrm{b}}$ Embrapa Amapá, Macapá, AP, Brazil \\ ${ }^{\mathrm{c}}$ Postgraduate Program in Biotechnology and Biodiversity (Bionorte), Federal University of Acre (UFAC), AC, Brazil \\ ${ }^{\mathrm{d}}$ Interdisciplinary Center for Marine and Environmental Research (CIIMAR), Porto, Portugal \\ ${ }^{\mathrm{e}}$ Abel Salazar Institute of Biomedical Sciences (ICBAS), University of Porto, Porto, Portugal
}

A R T I C L E I N F O

\section{Keywords:}

Arapaima gigas

Bacteria

Freshwater fish

Immunostimulant

Saccharomyces cerevisiae

\begin{abstract}
A B S T R A C T
The current study tested the efficacy of a dietary immunostimulant additive (Aquate Fish ${ }^{\mathrm{TM}}{ }^{\circ}$ ) on the growth performance, and on the physiological and immune responses of Arapaima gigas. Two trials were carried out: a feeding trial for 30 days with the experimental diets and a challenge trial for 7 days, in which fish were bacterial challenge (Aeromonas hydrophila) following by $60 \mathrm{~s}$ handling stress. During the feeding trial, fingerlings were fed diets supplemented with 0 (control), 6, 9 and $12 \mathrm{~g}$ Aquate Fish $^{\mathrm{TM}} / \mathrm{kg}$ diet. Dietary supplementation did not influence feed intake, feed conversion and condition factor, but increased the final biomass, number of erythrocytes, thrombocytes, leukocytes, lymphocytes, monocytes, hemoglobin, glucose, globulins and plasma triglycerides in fish fed at a concentration of $12 \mathrm{~g} / \mathrm{kg}$ diet. After bacterial infection, mortality occurred only in fish fed control treatment, whereas respiratory burst of leukocytes, number of leukocytes and lymphocytes increased in fish that received $12 \mathrm{~g}$ of dietary supplementation. The results indicated that dietary supplementation with $12 \mathrm{~g}$ of Aquate $\mathrm{Fish}^{\mathrm{TM}}{ }^{\oplus}$ improved biomass and immunity performance of $A$. gigas fingerlings, without negatively affecting blood biochemical parameters.
\end{abstract}

\section{Introduction}

The Amazon region has an important contribution to the cultivation of native and non-native fish species. Arapaima gigas Schinz, 1822 (pirarucu), a piscivorous air-breather fish, is among the main native species cultivated due to its high valued zootechnical characteristics such as fast growth, tolerance to the high density of storage and rusticity to the handling, high meat yield, besides having an excellent acceptance in the national and international market [1-4]. However, its production is still limited by the low availability, high cost of fingerlings [4] and economic losses, due to the large mortalities in the initial phase of production. The handling of $A$. gigas during routine practices in aquaculture production can cause stress to the fingerlings, reducing the resistance to diseases outbreaks, leading to mass mortalities $[1,3]$, caused mainly by aeromoniosis $[1,5]$.
Similar to other industries, aquaculture constantly requires new techniques to increase production and productivity, while maintaining fish health $[3,6,7]$. However, with the development of global aquaculture, several problems have arisen, including the deterioration of water quality, parasitic and bacterial diseases [1,3,4,7]. Diets supplemented with immunostimulants based on Saccharomyces cerevisiae, which contain beta-glucan polysaccharide, mannanoligosaccharides and chitin have been recommended for improvement in fish production [7-10]. Diets supplemented with immunostimulants may improve fish performance by establishing the intestinal microbiota and better preparing fish immune system. As a consequence, fish are more resistant to stress, including parasitic and infectious diseases [6-10]. Aquate $\mathrm{Fish}^{\mathrm{TM}}{ }^{\circ}$ is a commercial feed additive that may play a role in the fish defense systems. Pittman et al. [11] demonstrated that salmon fed diets supplemented with Aquate Fish ${ }^{\mathrm{TM}}{ }^{\circ}$ showed a significant increase in mucous

\footnotetext{
*Corresponding author. Embrapa Amapá, Rodovia Juscelino Kubitschek, km 5, 2600, 68903-419, Macapá, AP, Brazil.

E-mail address: marcos.tavares@embrapa.br (M. Tavares-Dias).
} 
cell density and cell sizes when compared with fish fed non-supplemented diets, and such effects disappeared after discontinuation of the treatment. Oreochromis niloticus fed diets supplemented with Aquate Fish $^{\mathrm{TM}}$ had lower ectoparasites levels, higher survival rate and improved in intestinal integrity $[12,13]$. Therefore, it is necessary to investigate the ideal concentrations of this commercial immunostimulant for the addition in the diet of this Amazonian fish, aiming the improvement of its immunity. This study investigated the effects of the Aquate Fish $^{\mathrm{TM}}$, a commercial immunostimulant, in the growth performance, physiology and immunity of $A$. gigas, evaluating the resistance against Aeromonas hydrophila.

\section{Materials and methods}

This study was carried out in accordance with the principles adopted by the Brazilian College of Animal Experimentation (COBEA) and approved by the Committee on Ethics in the Use of Animals (CEUA/ UFAC: 08/2014).

\subsection{Experimental diets}

Aquate Fish $^{\mathrm{TM} \oplus}$ (Alltech, USA) is a feed additive containing Saccharomyces cerevisiae extracts, zinc proteinate, seaweed meal, selenium and ascorbic acid. The experimental diets were prepared using commercial feed for carnivorous fish with a minimum of $45 \%$ crude protein (Presence, USA) and supplemented with four concentrations ( 0 , 6, 9 and $12 \mathrm{~g}$ Aquate Fish $^{\mathrm{Tm}} / \mathrm{kg}$ diet) defined from the manufacturer's recommendations. The chemical composition of the diets was performed in triplicate, according to the guidelines of the Association of Analysts of Analytical Chemistry [14] (Table 1).

\subsection{Fish and experimental design}

Arapaima gigas $(12.0 \pm 8.0 \mathrm{~cm})$ fingerlings were purchased from a commercial fish farm in Rio Branco (AC, Brazil) and transported to the Aquaculture and Fisheries Laboratory of Embrapa Amapá (AP, Brazil). During the acclimation period, fish were kept in $1000 \mathrm{~L}$ tanks with aeration and continuous flow of water and fed four times a day ad libitum with commercial feed for carnivores containing 55\% crude protein (Presence ${ }^{\bullet}$, São Paulo, Brazil).

During the feeding trial, 96 fingerlings $(59.3 \pm 21.3 \mathrm{~g}$ and $20.7 \pm 2.1 \mathrm{~cm}$ ) were distributed into 12 tanks of $100 \mathrm{~L}(\mathrm{n}=3$ tanks/ treatment; 8 fish/tank) and fed the experimental diets four times a day ( 8 a.m., 11 a.m., 2 p.m. and 5 p.m.). Fish were fed at $6 \%$ of biomass for 30 days. Water renewal and aeration within each tank were kept continuously, and dissolved oxygen $\left(6.6 \pm 0.3 \mathrm{mg} \mathrm{L}^{-1}\right)$, temperature $\left(29.3 \pm 0.1^{\circ} \mathrm{C}\right)$ and $\mathrm{pH}(5.3 \pm 0.3)$ were daily measured using a multiparameter probe (Horiba U52 model, Kyoto, Japan).

\subsection{Parameters of fish growth}

For the evaluation of growth performance, the following parameters were used:

a) Initial biomass $\left(\mathrm{kg} / \mathrm{m}^{3}\right)=$ initial average weight $\mathrm{x}$ total number of fish;

b) Final biomass $\left(\mathrm{kg} / \mathrm{m}^{3}\right)=$ final mean weight $\mathrm{x}$ total number of fish;

c) Daily feed intake $(\% \mathrm{BW} /$ day $)=$ average feed intake $(\mathrm{kg}) /$ average biomass gain $\left(\mathrm{kg} / \mathrm{m}^{3}\right)$;

d) Daily feed consumption = feed quantity (g)/days;

e) Daily weight gain = Weight gain (g)/time (days);

f) Weight gain = (final weight - initial weight);

g) Specific growth rate (SGR) $=($ ln final weight $-\ln$ initial weight $) x$ 100/(days);

h) Food efficiency (FE) $=100 \times$ [weight gain $(\mathrm{g}) /$ amount of ingested feed $(\mathrm{g})]$;

i) Relative condition factor, according to method recommended by Le Cren [15];

j) Hepatosomatic index (HSI, \%): liver weight (g)/body weight (g) x 100 ;

k) Viscerosomatic index (VSI, \%): viscera weight (g)/body weight (g) x 100 .

\subsection{Blood parameters and respiratory activity of leukocytes}

After the feeding trial, blood from four fish from each replicate tank (8 per treatment) were sampled by puncture of the caudal vessel in syringes containing sodium heparin $\left(5000 \mathrm{UI} \mathrm{mL}^{-1}\right)$. Blood was divided into two aliquots. An aliquot of blood was used to determine the hematocrit by the microhematocrit method, total erythrocytes count in the Neubauer chamber, and the hemoglobin concentration by the cyanometahemoglobin method. With these data, the hematometric indexes of Wintrobe were calculated: mean corpuscular volume (MCV) and mean corpuscular hemoglobin concentration (MCHC). Blood extensions were made and panchromically stained with a combination of May Grünwald-Giemsa-Wright, for differential leukocyte count in up to 200 cells of interest, at each extension. These blood extensions were also used to determine the number of leukocytes and total thrombocytes [16]. The nomenclature of leukocyte populations followed the recommendations of Tavares-Dias et al. [17]. The respiratory burst activity was determined according to method of Biller-Takahashi et al. [18]. Briefly, $100 \mu \mathrm{L}$ of heparinized blood was added to $100 \mu \mathrm{L}$ of $0.2 \%$ nitroblue tetrazolium solution (Sigma, St. Louis, MO, USA) and the final solution was homogenized and incubated for $30 \mathrm{~min}$ at $25^{\circ} \mathrm{C}$. After incubation and a second homogenization, $50 \mu \mathrm{L}$ from the solution were added to $1 \mathrm{ml}$ of $N, N$-dimethyl formamide (Sigma, St. Louis, MO, USA). This solution was then homogenized and centrifuged at $3000 \mathrm{~g}$ during 5 min. The optical density of supernatant was determined on spectrophotometer (Biospectro SP-220, Curitiba, Brazil) at $540 \mathrm{~nm}$.

The second aliquot of blood was centrifuged at $75 \mathrm{G}$ for $5 \mathrm{~min}$ (Mod.

Table 1

Basal composition of commercial ration and proximate composition of the experimental diets.

\begin{tabular}{|c|c|c|c|c|c|}
\hline Parameters & Manufacturer's data & \multicolumn{4}{|c|}{ Concentration of diets } \\
\hline Crude protein (\%) & 45 & $48.4 \pm 0.6^{\mathrm{a}}$ & $47.4 \pm 0.1^{\mathrm{a}}$ & $47.6 \pm 0.6^{\mathrm{a}}$ & $47.7 \pm 0.8^{\mathrm{a}}$ \\
\hline Ethereal extract (\%) & 9 & $2.8 \pm 0.5^{\mathrm{a}}$ & $5.6 \pm 1.7^{\mathrm{b}}$ & $4.3 \pm 0.05^{\mathrm{b}}$ & $4.1 \pm 0.1^{\mathrm{b}}$ \\
\hline Ashes (\%) & 16 & $10.6 \pm 0.1^{\mathrm{a}}$ & $10.7 \pm 0.2^{\mathrm{a}}$ & $10.6 \pm 0.04^{\mathrm{a}}$ & $10.5 \pm 0.1^{\mathrm{a}}$ \\
\hline Phosphorous (\%) & 1 & $1.3 \pm 0.1^{\mathrm{a}}$ & $1.2 \pm 0.04^{\mathrm{a}}$ & $1.5 \pm 0.3^{\mathrm{a}}$ & $1.6 \pm 0.07^{\mathrm{a}}$ \\
\hline Calcium (\%) & $2-3$ & $0.2 \pm 0.5^{\mathrm{a}}$ & $0.2 \pm 0.02^{\mathrm{a}}$ & $0.2 \pm 0.02^{\mathrm{a}}$ & $0.1 \pm 0^{\mathrm{a}}$ \\
\hline
\end{tabular}

Mean values \pm standard deviation. Values followed by different letters, on the same line, indicate difference between treatments by the Tukey test $(\mathrm{p}<0.05)$. 
5424, Hamburg, Germany) to obtain plasma and determine the concentration of glucose, total protein, albumin, total cholesterol and triglycerides using commercial reagent kits (Biotécnica, MG, Brazil), with absorbance readings performed in a spectrophotometer (Biospectro SP220, Curitiba, Brazil). Globulins content was determined subtracting albumin from total protein levels.

\subsection{Challenge with inoculation of Aeromonas hydrophila and stress}

After 30 days of feeding trial, other four fish from each replicate (8 fish/treatment) were challenged with Aeromonas hydrophilla (ATCC:7966). The fish were inoculated intraperitoneally with $1.8 \times 10^{8}$ UFC $\mathrm{mL}^{-1}$, the lethal concentration $\left(\mathrm{LC}_{50-96 \mathrm{~h}}\right)$ for $A$. gigas [1]. Mortality and clinical signs of bacteriosis were observed for 7 days, after which the surviving fish were subjected to handling stress. The fish were captured individually and subjected to stress by allowing them to struggle out of the water for $60 \mathrm{~s}[19,20]$. After $6 \mathrm{~h}$ of handling stress and challenge with $A$. hydrophilla, blood was sampled from each fish as previously mentioned and divided into two aliquots for determination of hematocrit, hemoglobin concentration, number of total erythrocytes, thrombocytes, leukocytes and leukocyte respiratory activity, levels of glucose, total protein, albumin, cholesterol, triglycerides and globulins, as described in item 2.4.

\subsection{Statistical analyses}

All data were evaluated on the assumptions of normality and homoscedasticity using Shapiro-Wilk and Bartlett, respectively. Data that showed a normal distribution were analyzed using variance analysis (ANOVA - One Way) followed by the Tukey test, to compare the means. Data that not showed a normal distribution were analyzed using Kruskal-Wallis test, and Dunn test were used to assess differences among medians [21].

\section{Results}

After the feeding trial, most of the growth performance parameters (body length, feed intake, feed conversion, daily weight gain, condition factor and VSI) did not vary with the dietary treatments ( $p>0.05$ ). There was, however, an increase in the final biomass in fish fed the diet with $12 \mathrm{~g}$ of the additive, and a decrease in daily weight gain, weight gain, SGR and HSI in the fish fed $6 \mathrm{~g}$ of the additive (Table 2).

Hematocrit, MCHC, respiratory burst, total protein, albumin and number of eosinophils did not vary with the dietary treatment, whereas the number of erythrocytes, leukocytes, lymphocytes, monocytes, thrombocytes, hemoglobin, glucose, plasma globulins and triglycerides were significantly increased $(\mathrm{p}<0.05)$ with the addition of $12 \mathrm{~g}$ Aquate Fish $^{\mathrm{Tm}} / \mathrm{kg}$ diet. Plasma cholesterol showed a significantly increase in fish fed $6 \mathrm{~g}$ and $12 \mathrm{~g}$ Aquate Fish $^{\mathrm{Tm}} / \mathrm{kg}$ diet when compared to fish fed the control diet and $9 \mathrm{~g}$ Aquate $\mathrm{Fish}^{\mathrm{T \textrm {m } ^ { \circ }}} / \mathrm{kg}$ diet. Conversely, MCV decreased $(\mathrm{p}<0.05)$ in fish fed $12 \mathrm{~g}$ Aquate Fish $^{\mathrm{TM}} / \mathrm{kg}$ diet when compared with the fish fed $9 \mathrm{~g}$ Aquate $\mathrm{Fish}^{\mathrm{TM}} / \mathrm{kg}$ diet. The number of neutrophils decreased $(\mathrm{p}<0.05)$ in fish fed $9 \mathrm{~g}$ Aquate $\mathrm{Fish}^{\mathrm{Tm}}{ }^{\bullet} / \mathrm{kg}$ diet when compared to the other treatments (Table 3 ).

After pathogen challenge and handling stress, detection of fish mortality occurred only in fish fed non-supplemented diets (control). Post infection values of Kn, VSI, HSI, glucose, albumin, hematocrit, MCHC, number of monocytes, neutrophils and eosinophils did not vary among the dietary treatments $(\mathrm{p}>0.05)$. Nevetheless, protein and globulin levels were significantly higher and MCV was lower $(\mathrm{p}<0.05)$ in fish fed with $6 \mathrm{~g}$ Aquate $\mathrm{Fish}^{\mathrm{TM}} / \mathrm{kg}$ diet than fish fed control diet. Plasma cholesterol was higher in fish supplemented with $6 \mathrm{~g}$ Aquate Fish $^{\mathrm{Tm}}{ }^{\circ} / \mathrm{kg}$ than in fish fed with $9 \mathrm{~g}$ and $12 \mathrm{~g}$ Aquate $\mathrm{Fish}^{\mathrm{TM}}{ }^{\circ} /$ $\mathrm{kg}$ diet $(\mathrm{p}<0.05)$. Plasma triglyceride levels were higher in fish fed $9 \mathrm{~g}$ Aquate $\mathrm{Fish}^{\mathrm{Tm}}{ }^{\circ} / \mathrm{kg}$ diet than in fish fed the control diet. Respiratory burst increased $(\mathrm{p}<0.05)$ in fish fed diet supplemented with $12 \mathrm{~g}$ Aquate Fish ${ }^{\mathrm{Tm}}$ when compared with the other treatments, whereas the number of thrombocytes increased compared to control fish ( $\mathrm{p}<0.05)$. The number of total leukocytes and lymphocytes increased in fish fed with $6 \mathrm{~g}$ Aquate Fish $^{\mathrm{TM} \mathrm{m}^{\oplus}}(\mathrm{p}<0.05)$ when compared with fish fed control diet (Table 4).

\section{Discussion}

Currently, new feeding practices play an important role in global aquaculture. The addition of feed additives to improve dietary quality is currently a common practice by many feed manufacturers to achieve better fish performance [7]. In the current study, the dietary supplementation Aquate $\mathrm{Fish}^{\mathrm{Tm}}{ }^{\circ}$ for a duration of 30 days did not influence the survival, body length, feed intake, feed conversion, condition factor in A. gigas, fish, but increased biomass in fish supplemented with $12 \mathrm{~g}$ of this immunostimulant. Some zootechnical results varied with the level of Aquate Fish $^{\mathrm{Tm}}{ }^{\oplus}$ supplementation. Some parameters showed improvement and other inhibition of performance with the dietary inclusion of Aquate Fish $^{\mathrm{TM}}{ }^{\varpi}$. Pádua et al. [13] demonstrated that $O$. niloticus fed diets supplemented with Aqute Fish ${ }^{\mathrm{TM}}$ had a higher survival rate, but occurred no effect on specific growth rate and weight gain. MycosorbA $+{ }^{\circ}$, a commercial immunostimulant containing mannanoligosaccharides derived from yeasts and algae did not have an effect on growth performance in A. gigas [2]. Conversely, Epinephelus coioides fed diet supplemented with $S$. cerevisiae showed improved weight gain and feed efficiency [22]. Supplementation with $0.1 \%$ of $S$. cerevisiae in the

Table 2

Growth performance parameters of Arapaima gigas fed the experimental diets for 30 days.

\begin{tabular}{|c|c|c|c|c|}
\hline \multirow[t]{2}{*}{ Parameters } & \multicolumn{4}{|c|}{ Concentration of diets } \\
\hline & $0 \mathrm{~g} / \mathrm{kg}(\mathrm{N}=24)$ & $6 \mathrm{~g} / \mathrm{kg}(\mathrm{N}=24)$ & $9 \mathrm{~g} / \mathrm{kg}(\mathrm{N}=24)$ & $12 \mathrm{~g} / \mathrm{kg}(\mathrm{N}=24)$ \\
\hline Initial length $(\mathrm{cm})$ & $20.6 \pm 1.8^{\mathrm{a}}$ & $20.6 \pm 1.7^{\mathrm{a}}$ & $20.6 \pm 1.6^{\mathrm{a}}$ & $21.1 \pm 1.7^{\mathrm{a}}$ \\
\hline Final length (g) & $33.2 \pm 2.1^{\mathrm{a}}$ & $31.6 \pm 1.7^{\mathrm{b}}$ & $31.6 \pm 2.1^{\mathrm{b}}$ & $33.9 \pm 2.0^{\mathrm{a}, \mathrm{b}}$ \\
\hline Initial biomass $\left(\mathrm{kg} / \mathrm{m}^{3}\right)$ & $2.7 \pm 5.7^{\mathrm{a}}$ & $2.6 \pm 5.6^{\mathrm{a}}$ & $2.9 \pm 6.0^{\mathrm{a}}$ & $2.9 \pm 5.8^{\mathrm{a}}$ \\
\hline Final biomass $\left(\mathrm{kg} / \mathrm{m}^{3}\right)$ & $9.4 \pm 8.1^{\mathrm{a}}$ & $7.7 \pm 6.9^{\mathrm{a}}$ & $9.8 \pm 8.2^{\mathrm{a}}$ & $10.6 \pm 8.8^{\mathrm{b}}$ \\
\hline Daily weight gain (g) & $5.5 \pm 0.1^{\mathrm{b}}$ & $3.9 \pm 0.8^{\mathrm{a}}$ & $4.6 \pm 0.7^{\mathrm{b}}$ & $5.3 \pm 0.4^{\mathrm{b}}$ \\
\hline Weight gain $(\mathrm{g})$ & $148.8 \pm 59.3^{\mathrm{a}}$ & $116.7 \pm 41.4^{\mathrm{b}}$ & $137.7 \pm 45.6^{\mathrm{a}}$ & $160.0 \pm 48.2^{\mathrm{a}}$ \\
\hline Daily feed intake (g) & $38.3 \pm 0.6^{\mathrm{a}}$ & $36.8 \pm 0.5^{\mathrm{a}}$ & $34.9 \pm 2.8^{\mathrm{a}}$ & $38.1 \pm 0.5^{\mathrm{a}}$ \\
\hline $\mathrm{AFC}$ & $1.1 \pm 0.1^{\mathrm{a}}$ & $1.3 \pm 0.3^{\mathrm{a}}$ & $1.1 \pm 0.2^{\mathrm{a}}$ & $1.0 \pm 0.06^{\mathrm{a}}$ \\
\hline SGR & $4.2 \pm 1.5^{\mathrm{b}}$ & $3.5 \pm 0.9^{\mathrm{b}}$ & $4.0 \pm 1.1^{\mathrm{b}}$ & $5.4 \pm 0.2^{\mathrm{a}}$ \\
\hline Feed efficiency (\%) & $94.4 \pm 10.7^{\mathrm{a}}$ & $88.8 \pm 19.6^{\mathrm{a}}$ & $88.0 \pm 14.1^{\mathrm{a}}$ & $98.2 \pm 5.6^{\mathrm{a}}$ \\
\hline Condition factor & $1.00 \pm 0.02^{\mathrm{a}}$ & $1.00 \pm 0.01^{\mathrm{a}}$ & $1.00 \pm 0.02^{\mathrm{a}}$ & $1.00 \pm 0.02^{\mathrm{a}}$ \\
\hline HSI (\%) & $2.0 \pm 0.2^{\mathrm{b}}$ & $1.7 \pm 0.4^{\mathrm{a}}$ & $2.2 \pm 4.5^{\mathrm{b}}$ & $2.0 \pm 0.2^{\mathrm{b}}$ \\
\hline VSI (\%) & $9.2 \pm 1.3^{\mathrm{a}}$ & $9.1 \pm 1.3^{\mathrm{a}}$ & $9.3 \pm 0.3^{\mathrm{a}}$ & $8.8 \pm 1.1^{\mathrm{a}}$ \\
\hline
\end{tabular}

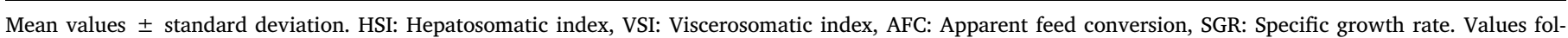
lowed by different letters, on the same line, indicate difference between treatments by the Tukey test $(p<0.05)$. 
Table 3

Plasma biochemical parameters and blood immune parameters of Arapaima gigas, after 30 days feeding the experimental diets.

\begin{tabular}{|c|c|c|c|c|}
\hline \multirow[t]{2}{*}{ Parameters } & \multicolumn{4}{|c|}{ Concentration of diets } \\
\hline & $0 \mathrm{~g} / \mathrm{kg}(\mathrm{N}=12)$ & $6 \mathrm{~g} / \mathrm{kg}(\mathrm{N}=12)$ & $9 \mathrm{~g} / \mathrm{kg}(\mathrm{N}=12)$ & $12 \mathrm{~g} / \mathrm{kg}(\mathrm{N}=12)$ \\
\hline Glucose $\left(\mathrm{mg} \mathrm{dL}^{-1}\right)$ & $24.2 \pm 12.6^{\mathrm{b}}$ & $35.0 \pm 11.2^{\mathrm{b}}$ & $20.0 \pm 12.3^{\mathrm{b}}$ & $44.9 \pm 14.8^{\mathrm{a}}$ \\
\hline Total protein $\left(\mathrm{g} \mathrm{dL}^{-1}\right)$ & $3.0 \pm 0.7^{\mathrm{a}}$ & $2.8 \pm 0.3^{\mathrm{a}}$ & $3.0 \pm 0.5^{\mathrm{a}}$ & $3.1 \pm 0.7^{\mathrm{a}}$ \\
\hline Total cholesterol (mg dL $\left.{ }^{-1}\right)$ & $92.2 \pm 33.3^{\mathrm{a}}$ & $146.8 \pm 47.1^{b}$ & $113.1 \pm 44.7^{\mathrm{a}}$ & $172.3 \pm 30.2^{\mathrm{b}}$ \\
\hline Triglycerides $\left(\mathrm{mg} \mathrm{dL}^{-1}\right)$ & $85.3 \pm 28.6^{\mathrm{a}}$ & $92.1 \pm 41.8^{\mathrm{a}}$ & $123.6 \pm 45.0^{\mathrm{a}}$ & $177.4 \pm 102.1^{\mathrm{b}}$ \\
\hline Albumin $\left(\mathrm{g} \mathrm{dL}^{-1}\right)$ & $0.9 \pm 0.6^{\mathrm{a}}$ & $1.0 \pm 0.46^{\mathrm{a}}$ & $1.2 \pm 0.7^{\mathrm{a}}$ & $0.6 \pm 0.3^{\mathrm{a}}$ \\
\hline Globulin $\left(\mathrm{g} \mathrm{dL}^{-1}\right)$ & $2.1 \pm 0.6^{\mathrm{a}, \mathrm{b}}$ & $1.8 \pm 0.6^{\mathrm{a}}$ & $1.8 \pm 0.6^{\mathrm{a}}$ & $2.5 \pm 0.7^{b}$ \\
\hline Hematocrit (\%) & $28.6 \pm 2.2^{\mathrm{a}}$ & $28.9 \pm 1.4^{\mathrm{a}}$ & $27.7 \pm 1.9^{\mathrm{a}}$ & $29.4 \pm 2.4^{\mathrm{a}}$ \\
\hline Hemoglobin $\left(\mathrm{g} \mathrm{dL}^{-1}\right)$ & $10.2 \pm 1.1^{\mathrm{a}, \mathrm{b}}$ & $9.9 \pm 0.9^{\mathrm{a}, \mathrm{b}}$ & $9,2 \pm 1,2^{\mathrm{a}}$ & $10,9 \pm 1,1^{\mathrm{b}}$ \\
\hline Erythrocytes $\left(\mathrm{x} 10^{6} \mu \mathrm{L}^{-1}\right.$ ) & $1.40 \pm 0.40^{\mathrm{a}, \mathrm{b}}$ & $1.30 \pm 0.30^{\mathrm{a}, \mathrm{b}}$ & $1.20 \pm 0.40^{\mathrm{a}}$ & $1.70 \pm 0,30^{\mathrm{b}}$ \\
\hline $\operatorname{MCV}\left(\mathrm{fL}^{-1}\right)$ & $221.1 \pm 60.2^{\mathrm{a}, \mathrm{b}}$ & $225.8 \pm 52.3^{\mathrm{a}, \mathrm{b}}$ & $249.1 \pm 61,7^{\mathrm{a}}$ & $179.3 \pm 37.5^{\mathrm{b}}$ \\
\hline $\mathrm{MCHC}\left(\mathrm{g} \mathrm{dL}^{-1}\right)$ & $35.7 \pm 4.5^{\mathrm{a}}$ & $34.2 \pm 2.7^{\mathrm{a}}$ & $33.1 \pm 2.7^{\mathrm{a}}$ & $37.1 \pm 3.6^{\mathrm{a}}$ \\
\hline Respiratory burst & $0.23 \pm 0.06^{\mathrm{a}}$ & $0.22 \pm 0.07^{\mathrm{a}}$ & $0.19 \pm 0.03^{\mathrm{a}}$ & $0.24 \pm 0.07^{\mathrm{a}}$ \\
\hline Thrombocytes (x $10^{3} \mu \mathrm{L}^{-1}$ ) & $19.2 \pm 5.6^{\mathrm{a}}$ & $27.5 \pm 6.7^{\mathrm{a}}$ & $24.4 \pm 7.8^{\mathrm{a}}$ & $40.3 \pm 9.6^{\mathrm{b}}$ \\
\hline Leukocytes $\left(x 10^{3} \mu \mathrm{L}^{-1}\right)$ & $152.4 \pm 42.4^{\mathrm{a}}$ & $160.3 \pm 36.0^{\mathrm{a}}$ & $145.3 \pm 45.8^{\mathrm{a}}$ & $212.9 \pm 41.8^{\mathrm{b}}$ \\
\hline Lymphocytes $\left(\times 10^{3} \mu \mathrm{L}^{-1}\right)$ & $74.7 \pm 24.7^{\mathrm{a}}$ & $78.2 \pm 20.9^{\mathrm{a}}$ & $82.7 \pm 29.1^{\mathrm{a}}$ & $122.3 \pm 30.9^{\mathrm{b}}$ \\
\hline Monocytes $\left(\times 10^{3} \mu \mathrm{L}^{-1}\right)$ & $4.5 \pm 3.2^{\mathrm{a}}$ & $4.3 \pm 3.2^{\mathrm{a}}$ & $4.9 \pm 2.9^{\mathrm{a}}$ & $10.0 \pm 4.8^{\mathrm{b}}$ \\
\hline Neutrophils (x $10^{3} \mu \mathrm{L}^{-1}$ ) & $70.9 \pm 18.7^{\mathrm{b}}$ & $74.8 \pm 16.6^{\mathrm{b}}$ & $55.3 \pm 16.6^{\mathrm{a}}$ & $76.6 \pm 15.5^{\mathrm{b}}$ \\
\hline Eosinophils $\left(\times 10^{3} \mu \mathrm{L}^{-1}\right.$ ) & $2.3 \pm 2.5^{\mathrm{a}}$ & $3.0 \pm 1.7^{\mathrm{a}}$ & $2.4 \pm 2.0^{\mathrm{a}}$ & $4.0 \pm 4.1^{\mathrm{a}}$ \\
\hline
\end{tabular}

Mean values \pm standard deviation. MCV: Mean corpuscular volume, MCHC: mean corpuscular hemoglobin concentration. Values followed by different letters, on the same line, indicate difference between treatments by the Dunn test $(\mathrm{p}<0.05)$.

diet of O. niloticus [23] and $2 \%$ in the diet of Huso huso [24], as well as $2 \%$ of $\beta$-glucan combined with mannanoligosaccharides in the diet of Piaractus mesopotamicus [9] improved fish growth performances. The previous studies indicated that $S$. cerevisiae-based products were efficient in promoting fish growth and potentially viable for aquaculture use from the production viewpoint.

Physiological indicators of health $[6,16]$ and immune status $[2,6,10]$ are often used to evaluate the efficacy of dietary supplementation of feed additives. In the current study, VSI and HSI of $A$. gigas fed with different Aquate Fish $^{\mathrm{TM}}$ levels were not altered, although plasma triglycerides, cholesterol and glucose increased in fish fed $12 \mathrm{~g}$ Aquate $\mathrm{Fish}^{\mathrm{Tm}}{ }^{\oplus}$. These results indicated that there was no change in the use of lipid and glycogen reserves, since fish did not undergo any food deprivation during the test. In contrast, no alteration in plasma levels of cholesterol, triglycerides and glucose of $H$. huso supplemented with $1-2 \%$ of $S$. cerevisiae in the diet were reported [24]. In the current study, dietary supplementation of Aquate $\mathrm{Fish}^{\mathrm{Tm}}{ }^{\circ}$ showed mixed effects on plasma biochemical and blood immune parameters. On one hand had no effect on hematocrit, MCHC, MCV, respiratory burst of leukocytes, total protein, albumin and number of eosinophils. Similarly, $P$. mesopotamicus supplemented with a combination of $1-8 \%$ of $\beta$-glucan and mannanoligosaccharides for 30 days, did not change the number of erythrocytes, hematocrit, hemoglobin, MCHC, VCM, and total plasma protein levels [9]. In $H$. huso supplemented with $1-2 \%$ of $S$. cerevisiae in the diet, for 42 days, no changes in plasma levels of total proteins, glucose, erythrocytes, hematocrit, hemoglobin, MCHC, MCV and

Table 4

Mortality, body, blood and immune parameters of Arapaima gigas fed for 30 days with the experimental diets following a bacterial challenge and handling stress.

\begin{tabular}{|c|c|c|c|c|}
\hline \multirow[b]{2}{*}{ Parameters } & \multicolumn{4}{|c|}{ Concentration of diets } \\
\hline & $0 \mathrm{~g} / \mathrm{kg}(\mathrm{N}=11)$ & $6 \mathrm{~g} / \mathrm{kg}(\mathrm{N}=12)$ & $9 \mathrm{~g} / \mathrm{kg}(\mathrm{N}=12)$ & $12 \mathrm{~g} / \mathrm{kg}(\mathrm{N}=12)$ \\
\hline Mortality (\%) & 8.3 & 0 & 0 & 0 \\
\hline Kn & $1.00 \pm 0.01^{\mathrm{a}}$ & $1.00 \pm 0.01^{\mathrm{a}}$ & $1.00 \pm 0.01^{\mathrm{a}}$ & $1.00 \pm 0.01^{\mathrm{a}}$ \\
\hline HSI (\%) & $2.0 \pm 0.4^{\mathrm{a}}$ & $1.7 \pm 0.4^{\mathrm{a}}$ & $1.7 \pm 0.5^{\mathrm{a}}$ & $1.5 \pm 0.3^{\mathrm{a}}$ \\
\hline VSI (\%) & $9.5 \pm 1.4^{\mathrm{a}}$ & $9.0 \pm 1.2^{\mathrm{a}}$ & $9.1 \pm 1.1^{\mathrm{a}}$ & $8.2 \pm 1.0^{\mathrm{a}}$ \\
\hline Glucose $\left(\mathrm{mg} \mathrm{dL}^{-1}\right)$ & $46.3 \pm 27.8^{\mathrm{a}}$ & $44.3 \pm 17.2^{\mathrm{a}}$ & $43.7 \pm 7.1^{\mathrm{a}}$ & $64.9 \pm 18.6^{\mathrm{a}}$ \\
\hline Total protein $\left(\mathrm{g} \mathrm{dL}^{-1}\right)$ & $2.8 \pm 0.2^{\mathrm{b}}$ & $3.6 \pm 0.4^{\mathrm{a}}$ & $3.2 \pm 0.3^{\mathrm{a} . \mathrm{b}}$ & $3.0 \pm 0.6^{\mathrm{b}}$ \\
\hline Total cholesterol $\left(\mathrm{mg} \mathrm{dL}^{-1}\right)$ & $148.7 \pm 27.8^{\mathrm{a} . \mathrm{b}}$ & $193.1 \pm 30.9^{\mathrm{a}}$ & $137.7 \pm 64.2^{\mathrm{b}}$ & $98.0 \pm 39.6^{\mathrm{b}}$ \\
\hline Triglycerides $\left(\mathrm{mg} \mathrm{dL}^{-1}\right)$ & $36.4 \pm 16.8^{\mathrm{a}}$ & $65.4 \pm 42.3^{\text {a.b }}$ & $86.4 \pm 31.7^{\mathrm{b}}$ & $55.5 \pm 21.4^{\text {a.b }}$ \\
\hline Albumin $\left(\mathrm{g} \mathrm{dL}^{-1}\right)$ & $1.1 \pm 0.3^{\mathrm{a}}$ & $1.1 \pm 0.4^{\mathrm{a}}$ & $1.1 \pm 0.4^{\mathrm{a}}$ & $0.9 \pm 0.4^{\mathrm{a}}$ \\
\hline Globulin $\left(\mathrm{g} \mathrm{dL}^{-1}\right)$ & $1.7 \pm 0.4^{\mathrm{b}}$ & $2.7 \pm 0.5^{\mathrm{a}}$ & $2.1 \pm 0.6^{\mathrm{a} . \mathrm{b}}$ & $2.0 \pm 0.6^{\mathrm{a} . \mathrm{b}}$ \\
\hline Hematocrit (\%) & $28.6 \pm 3.4^{\mathrm{a}}$ & $27.5 \pm 2.8^{\mathrm{a}}$ & $28.7 \pm 2.2^{\mathrm{a}}$ & $29.0 \pm 2.0^{\mathrm{a}}$ \\
\hline Hemoglobin $\left(\mathrm{g} \mathrm{dL}^{-1}\right)$ & $10.2 \pm 1.4^{\mathrm{b}}$ & $11.0 \pm 2.2^{\mathrm{a} . \mathrm{b}}$ & $10.3 \pm 2.8^{\mathrm{b}}$ & $13.2 \pm 3.1^{\mathrm{a}}$ \\
\hline Erythrocytes $\left(\times 10^{6} \mu^{-1}\right)$ & $2.20 \pm 0.40^{\mathrm{b}}$ & $2.30 \pm 0.01^{\mathrm{a}}$ & $2.60 \pm 0.2^{\mathrm{a} . \mathrm{b}}$ & $2.50 \pm 0.4^{\mathrm{a} . \mathrm{b}}$ \\
\hline $\operatorname{MCV}\left(\mathrm{fL}^{-1}\right)$ & $134.7 \pm 16.8^{\mathrm{b}}$ & $101.6 \pm 28.5^{\mathrm{a}}$ & $113.2 \pm 13.8^{\mathrm{a} . \mathrm{b}}$ & $120.7 \pm 25.3^{\text {a.b }}$ \\
\hline $\mathrm{MCHC}\left(\mathrm{g} \mathrm{dL}^{-1}\right)$ & $35.8 \pm 3.5^{\mathrm{a}}$ & $39.8 \pm 6.1^{\mathrm{a}}$ & $35.9 \pm 10.2^{\mathrm{a}}$ & $44.5 \pm 11.2^{\mathrm{a}}$ \\
\hline Respiratory burst & $0.16 \pm 0.05^{\mathrm{b}}$ & $0.20 \pm 0.04^{\mathrm{b}}$ & $0.18 \pm 0.03^{b}$ & $0.29 \pm 0.09^{\mathrm{a}}$ \\
\hline Thrombocytes (x $10^{3} \mu \mathrm{L}^{-1}$ ) & $40.7 \pm 9.4^{c}$ & $55.1 \pm 19.4^{\mathrm{a}, \mathrm{c}}$ & $59.4 \pm 10.8^{\mathrm{a}, \mathrm{b}}$ & $73.2 \pm 15.9^{b}$ \\
\hline Leukocytes $\left(\times 10^{3} \mu \mathrm{L}^{-1}\right)$ & $258.5 \pm 44.9^{\mathrm{a}}$ & $355.0 \pm 125.6^{\mathrm{b}}$ & $310.0 \pm 26.8^{\mathrm{a}, \mathrm{b}}$ & $329.7 \pm 55.9^{\mathrm{a}, \mathrm{b}}$ \\
\hline Lymphocytes $\left(\times 10^{3} \mu \mathrm{L}^{-1}\right)$ & $167.2 \pm 28.9^{\mathrm{a}}$ & $236.1 \pm 83.9^{\mathrm{b}}$ & $202.4 \pm 22.8^{\mathrm{a}, \mathrm{b}}$ & $218.8 \pm 54.4^{\mathrm{a}, \mathrm{b}}$ \\
\hline Monocytes $\left(\times 10^{3} \mu \mathrm{L}^{-1}\right)$ & $10.8 \pm 6.4^{\mathrm{a}}$ & $13.5 \pm 8.4^{\mathrm{a}}$ & $16.7 \pm 20.1^{\mathrm{a}}$ & $18.0 \pm 6.1^{\mathrm{a}}$ \\
\hline Neutrophils $\left(\mathrm{x} 10^{3} \mu \mathrm{L}^{-1}\right.$ ) & $77.3 \pm 19.7^{\mathrm{a}}$ & $99.6 \pm 47.1^{\mathrm{a}}$ & $84.9 \pm 20.1^{\mathrm{a}}$ & $88.1 \pm 36.8^{\mathrm{a}}$ \\
\hline Eosinophils $\left({\left.\mathrm{x} 10^{3} \mu \mathrm{L}^{-1}\right)}^{-1}\right.$ & $3.2 \pm 2.1^{\mathrm{a}}$ & $5.8 \pm 8.0^{\mathrm{a}}$ & $6.0 \pm 4.1^{\mathrm{a}}$ & $4.8 \pm 4.3^{\mathrm{a}}$ \\
\hline
\end{tabular}

Mean expression values \pm standard deviation. Mean values \pm standard deviation. MCV: Mean corpuscular volume, MCHC: mean corpuscular hemoglobin concentration. Values followed by different letters, on the same line, indicate difference between treatments by the Dunn test (p $<0.05)$. HSI: Hepatosomatic index, VSI: Viscerosomatic index, Kn: Relative factor of condition. 
number of leukocytes were reported [24].

On the other hand, Aquate Fish ${ }^{\mathrm{Tm}}$ increased the number of several blood cells, such as the total erythrocytes, leukocytes, lymphocytes, monocytes, thrombocytes, indicating an improvement of the immune defense response in the A. gigas. Amin et al. [8] observed an increase in the activity of phagocytosis and lysozyme, number of leukocytes and percentage of monocytes and neutrophils in O. niloticus supplemented for 42 days with $0.3 \%$ glucan, indicating an improvement in the innate immunity.

Although handling is a routine practice in fish farming of any kind, it can cause stress during A. gigas production, resulting in alterations in fish resistance to diseases [1,3]. In the current study, the use of $12 \mathrm{~g}$ Aquate Fish $^{\mathrm{Tm}}{ }^{\mathrm{\omega}}$ caused a reduction of fish mortality after pathogen challenge and improved cellular immune response and respiratory burst of leukocytes in A. gigas after experimental infection with $A$. hydrophila and management stress. Similarly, in $P$. mesopotamicus has been demonstrated that supplementation with 0.1 or $1.0 \%$-glucan, respiratory burst of leukocytes, complement hemolytic activity, lysozyme activity and number of leukocytes increased after challenge with $A$. hydrophila, reducing fish mortality [25]. The addition of 0.2 and $0.4 \%$ of Glucan-MOS ${ }^{\circ}$ was also sufficient to positively influence these immune parameters in $P$. mesopotamicus after challenge of stress and infection with $A$. hydrophila [10]. In $E$. coioides supplemented with different concentrations of $S$. cerevisiae and challenged with inoculation of Streptococcus sp. and iridovirus, phagocytic activity, respiratory burst of leukocytes, number of leukocytes in the kidney, lysozyme activity and alternative complement activity increased in fish fed with $10^{5}$ and $10^{7}$ UFC $\mathrm{kg}^{-1}$ of diet, reducing fish mortality [22]. Therefore, these immunostimulatory supplements improved the innate immunity of the fish, increasing their survival after challenge of immune resistance.

\section{Conclusions}

The results of this study indicate that supplementation with $12 \mathrm{~g}$ of Aquate $\mathrm{Fish}^{\mathrm{TM}} /{ }^{\circ} \mathrm{kg}$ of diet improved the biomass and immunity performance of $A$. gigas fingerlings, without negatively impacting the hematological parameters investigated. Finally, the 30-day supplementation period was sufficient to stimulate growth performance and to minimize handling stress and $A$. hydrophila infection, modulating innate immunity responses.

\section{Acknowledgments}

This study was funded by the Coordenação de Aperfeiçoamento de Pessoal de Nível Superior (CAPES), through the Pro-Amazônia project (\# 230238.00754/2013-61) and a doctoral grant was granted to the first author. The authors also thank the Conselho Nacional de Desenvolvimento Científico e Tecnológico (CNPq) for the productivity research grant awarded to Dr. M. Tavares-Dias (\# 303013/2015-0).

\section{References}

[1] M.K.R. Dias, L.S. Sampaio, A.A. Proietti-Junior, E.T.O. Yoshioka, D.P. Rodrigues, A.F.R. Rodriguez, R.A. Ribeiro, F.S.E.D.V. Faria, R.O.A. Ozório, M. Tavares-Dias, Lethal dose and clinical signs of Aeromonas hydrophila in Arapaima gigas (Arapaimidae), the giant fish from Amazon, Vet. Microbiol. 188 (2016) 12-15, https://doi.org/10.1016/j.vetmic.2016.04.001.

[2] M.D.F.G. Hoshino, R.G.B. Marinho, D.F. Pereira, E.T.O. Yoshioka, M. Tavares-Dias, R.O.A. Ozório, A.F.R. Rodriguez, R.A. Ribeiro, F.S.E.D.V. Faria, Hematological and biochemical responses of pirarucu (Arapaima gigas, Arapaimidae) fed with diets containing a glucomannan product derived from yeast and algae, Acta Amazonica
47 (2017) 87-94, https://doi.org/10.1590/1809-4392201700781.

[3] A.F. Lima, A.P. Rodrigues, L.K.F. Lima, P.O. Maciel, F.P. Rezende, L.E.L. Freitas, M. Tavares-Dias, T.A. Bezerra, Alevinagem, recria e engorda do pirarucu, Brasília, DF, Embrapa, (2017).

[4] H.P. Santana, G.M. Morey, J.P. Lima, J.C.O. Malta, Influência de metazoários parasitas na morte de juvenis de Arapaima gigas (Schinz, 1822) criados em uma piscicultura na Amazônia brasileira, Rev. Bras. Zoociencias 18 (2017) 77-90.

[5] A.A. Proietti-Junior, L.S. Lima, F.M.N. Cardoso, D.P. Rodrigues, M. Tavares-Dias, Bacterioses em alevinos de pirarucu de cultivo, com ênfase em Edwardsielose e Aeromonose, Comunicado Técnico 149, Macapá, Embrapa Amapá, (2017).

[6] Ü. Acar, O.S. Kesbiç, S. Yılmaz, N. Gültepe, A. Türker, Evaluation of the effects of essential oil extracted from sweet orange peel (Citrus sinensis) on growth rate of tilapia (Oreochromis mossambicus) and possible disease resistance against Streptococcus iniae, Aquaculture 437 (2015) 282-286, https://doi.org/10.1016/j. aquaculture.2014.12.015.

[7] W. Wang, J. Sun, C. Liu, Z. Xue, Application of immunostimulants in aquaculture: current knowledge and future perspectives, Aquacult. Res. 48 (2017) 1-23, https:// doi.org/10.1111/are.13161.

[8] M. Amin, D. Jusadi, A. Sukenda, E. Harris, Growth performance, non-specific immune and antioxidant response of juvenile tilapia Oreochromis sp. feeding on brewer's yeast Saccharomyces cerevisiae supplemented diet, Pakistan J. Biotechnol. 12 (2015) 139-148.

[9] H. Hisano, M.P. Soares, F.G. Luiggi, A.C. Arena, Dietary $\beta$-glucans and mannanoligosaccharides improve growth performance and intestinal morphology of juvenile pacu Piaractus mesopotamicus (Holmberg, 1887), Aquacult. Int. 26 (2018) 213-223, https://doi.org/10.1007/s10499-017-0210-6.

[10] M.P. Soares, F.C. Oliveira, I.L. Cardoso, E.C. Urbinati, C.M. Campos, H. Hisano, Glucan-MOS improved growth and innate immunity in pacu stressed and experimentally infected with Aeromonas hydrophilla, Fish Shellfish Immunol. 73 (2018) 133-140, https://doi.org/10.1016/j.fsi.2017.11.046.

[11] K. Pittman, New research tool reveals mucosal interaction and dietary influence infighting sea lice infections, Aquafeed 5 (2013) 7-11.

[12] S.B. Pádua, R.N. Menezes-Filho, M.A.A. Belo, M.M. Nagata, A nutritional additive increases survival and reduces parasitism in Nile tilapia during masculinisation, AQUA Cul. Asia Pacific Mag. (2014) 24-27 Sep/Oct.

[13] S.B. Pádua, M.L. Martins, R.N. Menezes-Filho, M.M. Nagata, Uso de Aquate Fish ${ }^{\text {TM }}$ durante a formação de juvenis de tilápia: aumento da resistência contra doenças, melhoria na integridade intestinal e no desempenho produtivo, Rev. Aquat. Feed (2015) 4-8 Jan/Feb.

[14] AOAC- Association of official analytical chemists, Official Methods of Analysis, sixteenth ed., AOAC, Arlington, 1995.

[15] E.D. Le Cren, The length-weight relationship and seasonal cycle in gonadal weight and condition in the perch (Perca fluviatilis), J. Anim. Ecol. 20 (1951) 201-219.

[16] M.J.T. Ranzani-Paiva, S.B. Pádua, M. Tavares-Dias, M.I. Egami, Métodos para análises hematológicas em peixes, EDUEM, Maringá, 2013.

[17] M. Tavares-Dias, J.F.M. Barcellos, J.L. Marcon, G.C. Menezes, E.A. Ono, E.G. Affonso, Hematological and biochemical parameters for the pirarucu Arapaima gigas Schinz, 1822 (Osteoglossiformes, Arapaimatidae) in net cage culture, Electron. J. Ichthyol. 2 (2007) 61-68.

[18] J.D. Biller-Takahashi, L.S. Takahashi, M.V. Saita, R.Y. Gimbo, E.C. Urbinati, Leukocytes respiratory burst activity as indicator of innate immunity of pacu Piaractus mesopotamicus, Braz. J. Biol. 73 (2013) 425-429, https://doi.org/10. 1590/S1519-69842013000200026.

[19] B.A. Barton, R.E. Zitzow, Physiological responses of juvenile walleyes to handling stress with recovery in saline water, Prog. Fish-Cult. 57 (1995) 267-276, https:// doi.org/10.1577/1548-8640(1995)057<0267:PROJWT > 2.3.CO;2.

[20] E.L. Davis, C.B. Schreck, The energetic response to handling stress in juvenile Coho Salmo, Trans. Am. Fish. Soc. 126 (1997) 248-258, https://doi.org/10.1577/1548 8659(1997) $126<0248$ :TERTHS > 2.3.CO; 2 .

[21] J.H. Zar, Biostatistical Analysis, fifth ed., Prentice-Hall, New Jersey, 2010.

[22] C.H. Chiu, C.H. Cheng, W.R. Gua, Y.K. Guu, W. Cheng, Dietary administration of the probiotic, Saccharomyces cerevisiae $\mathrm{P} 13$, enhanced the growth, innate immune responses, and disease resistance of the grouper, Epinephelus coioides, Fish Shellfish Immunol. 29 (2010) 1053-1059, https://doi.org/10.1016/j.fsi.2010.08.019.

[23] M. Lara-Flores, M.A. Olvera-Novoa, B.E. Guzmán-Méndez, W. López-Madrid, Use of the bacteria Streptococcus faecium and Lactobacillus acidophilus, and the yeast Saccharomyces cerevisiae as growth promoters in Nile tilapia (Oreochromis niloticus), Aquaculture 216 (2003) 193-201, https://doi.org/10.1016/S0044-8486(02) 00277-6.

[24] S.H. Hoseinifar, A. Mirvaghefi, D.L. Merrifield, The effects of dietary inactive brewer's yeast Saccharomyces cerevisiae var. ellipsoideus on the growth, physiological responses and gut microbiota of juvenile beluga (Huso huso), Aquaculture 318 (2011) 90-94, https://doi.org/10.1016/j.aquaculture.2011.04.043.

[25] J.D. Biller-Takahashi, L.S. Takahashi, C.M. Marzocchi-Machado, F.S. Zanuzzo, E.C. Urbinati, Disease resistance of pacu Piaractus mesopotamicus (Holmberg, 1887) fed with $\beta$-glucan, Braz. J. Biol. 74 (2014) 698-770, https://doi.org/10.1590/bjb. 2014.0083. 